\title{
Ecological and Physiological Studies on the Vegetation of Mt. Shimagare
}

\author{
I. Preliminary Survey of the Vegetation of Mt. Shimagare \\ by Yasuyuki Oshima*, Makoto KImura*, Hideo IWAKI** \\ and Sumio Kurorwa** \\ 大島康行*, 木村允*, 岩城英夫**, 黑岩澄焳**：縞枯山の杖生についての \\ 生態学ならびに生理学的研究 I. 核枯山の植生の予備調查
}

Received May 21, 1958

Mt. Shimagare ( $2395 \mathrm{~m}$. above the sea) is one of the hills in the northern part of Yatsugatake dead volcano group, of which the highest peak is Mt. Akadake (2899 m.), in Nagano Pref., at a distance of $130 \mathrm{~km}$. NWW from Tokyo. In the dark green of the gentle southwest slope of Mt. Shimagare covered with subalpine coniferous forest, several whitish stripes horizontally running in parallel with each other can be seen in a distant view so distinctly that the mountain has been named "mountain with dead trees strips" according to its conspicuous physiognomy (Photo. 1,2 and Fig. 1). The vegetation consists of several forest units, each of which has a serial arrangement from very young tree offspring in higher part up to overmatured and dead trees of Abies Veitchii and A. Mariesii in lower part, just as the natural image of Wagner's border cuttings11) (Fig. 2). The whitish stripes are the dense stands of dead tree trunks of these conifers (Photo 3), and they will shift upwards in decades.

Okubo10), Yoshida and Yamanouchiri) have already surveyed the forests from the view- point of forestry. They collected a lot of preliminary informations on the size, density and growth of trees, and tried to discuss the origin and shifting of the dead trees strips, though rather speculatively. Therefore, these problems might be well worthy of more precise ecological and physiological investigations into the origin and maintenance of such forest unit arrangement, especially on the basis of the dry matter production ${ }^{1)}$ of the trees, because these investigations will bring many new findings about natural features of intra- and interspecific competitions and of plant succession, of which fundamentals have been studied theoretically and experimentally by

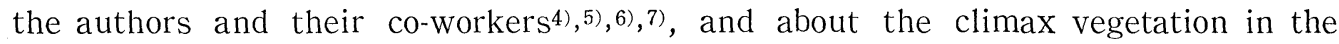
subalpine of central Japan.

* Department of Biology, Faculty of Science, Tokyo Metropolitan University, Setagaya, Tokyo, Japan。東京都立大学理学部生物学教室

** Botanical Institute, Faculty of Science, University of Tokyo, Hongo, Tokyo, Japan. 東京 大学理学部植物学教室 
In this first report, the results of the preliminary survey of the vegetation in 1957 will be discussed, referring to the papers of Okubo and of Yoshida and Yamanouchi before entering further the ecological and physiological studies on the vegetation and on the growth of the trees.

\section{General features}

The subalpine coniferous forests of Mt. Shimagare mainly consists of Abies Veitchii and A. Mariesii, being mixed with Picea jezoensis var. hondoensis, Betula Ermani and Sorbus sp. Such vegetation has been nominated by Nakano after his detailed studies on the vegetation of Mt. Yatsugatake and others, as Betuleto Ermani-Abietetum Veitchi association of a wide distributing Betulion Ermani alliance in subalpine coniferous forests in Japan. More strictly the vegetation of Mt. Shimagare will chiefly be classified into Pteridophyllosum sociation characterized by an obligate shade plant Pteridophyllum racemosum, of a subassociation Mariesetum in the association. On the southwest slope $\left(10^{\circ}-20^{\circ}\right)$ where the dead trees strips develop, the forests seem to be rather a consociation of the two Abies species, as Betula and Sorbus are scarcely mixed in the forests. The Abietum on the northeast slope $\left(20^{\circ}-25^{\circ}\right)$ has a considerable number of old trees of Betula Ermani and other deciduous species mixing.

Temperature and precipitation in the region of Mt. Shimagare will be able to assumed from the meteorological data of Kirigamine $(1925 \mathrm{~m}$. above the sea, $12 \mathrm{~km}$. NWW of Mt. Shimagare) in Table 1. The temperatures at $2250 \mathrm{~m}$. above the sea (the lower limit of the dead trees strips) and $2395 \mathrm{~m}$. (the top of the mountain) have been calculated with lapse rate of temperature between the two stations (mean lapse rate was ca. $7.1^{\circ}$ against $1000 \mathrm{~m}$. elevation).

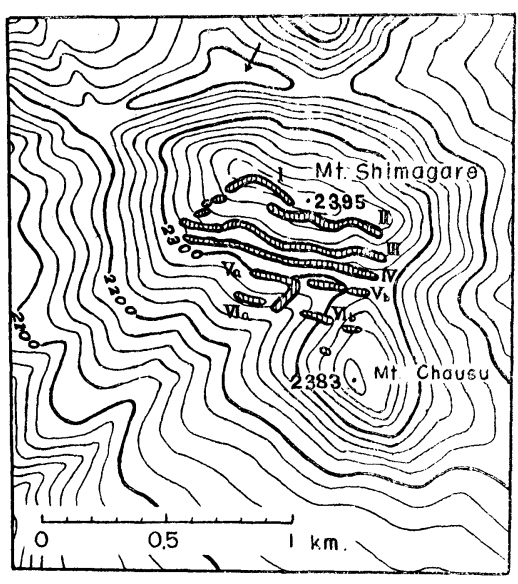

Fig. 1. Map showing the location of "dead trees strips" at Mt. Shimagare, which are corrected with the aerial photo of Geographical Survey.
The temperature climate at Mt. Shimagare is nearly same as that of Poronaisk in Saghalin $\left(49^{\circ} 12^{\prime} \mathrm{N}\right.$; min. $-17.5^{\circ}$ in Jan., max. $15.9^{\circ}$ in Aug., mean ann. temp. $\left.0.0^{\circ}\right)$. The precipitation at $\mathrm{Mt}$. Shimagare seems to be same as or probably somewhat higher than that of Kirigamine because of higher altitude, and this amount may be enough or sometimes too much for tree growth under such low temperature conditions, comparing to that the annual precipitation at Poronaisk is only $750 \mathrm{~mm}$., at Quebec in Canada $1073 \mathrm{~mm}$. (mean ann. temp. 3.6 ${ }^{\circ}$ ), and at Davos in Switzerland $994 \mathrm{~mm}$. (1561 m. above the sea; mean ann. temp. $\left.2.8^{\circ}\right)$.

Throughout the year west wind prevails on this slope of the mountain 10),12) causing 

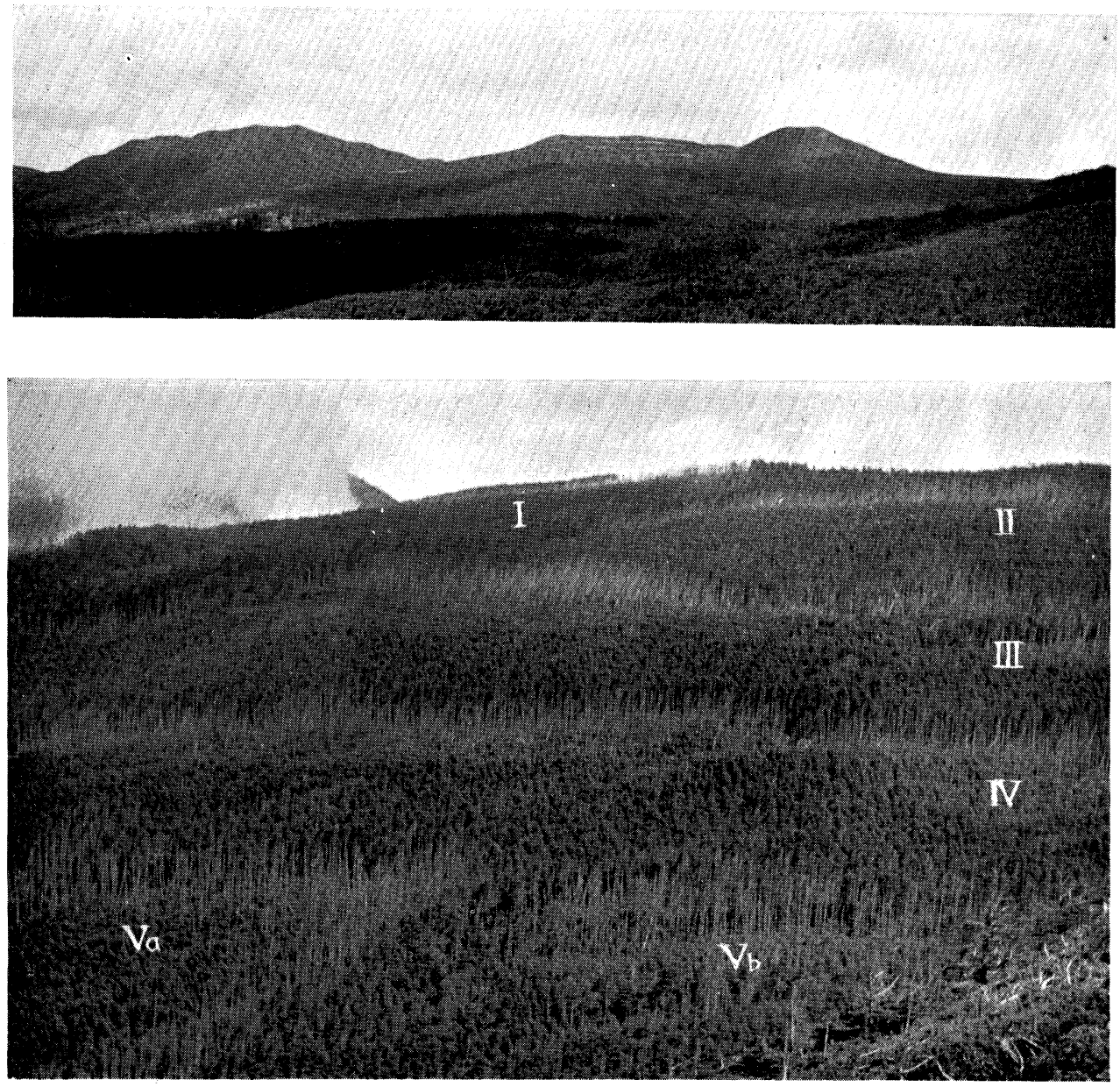

Photo 1. Mountains of the northern part of Yatsugatake. Left to right are Mt. Yokodake (2473 m.), Mt. Shimagare (2395 m.) and Mt. Chausu (2388 m).

Photo 2. Subalpine coniferous forest on the southwest slope of Mt. Shimagare, showing the "dead trees strips" 


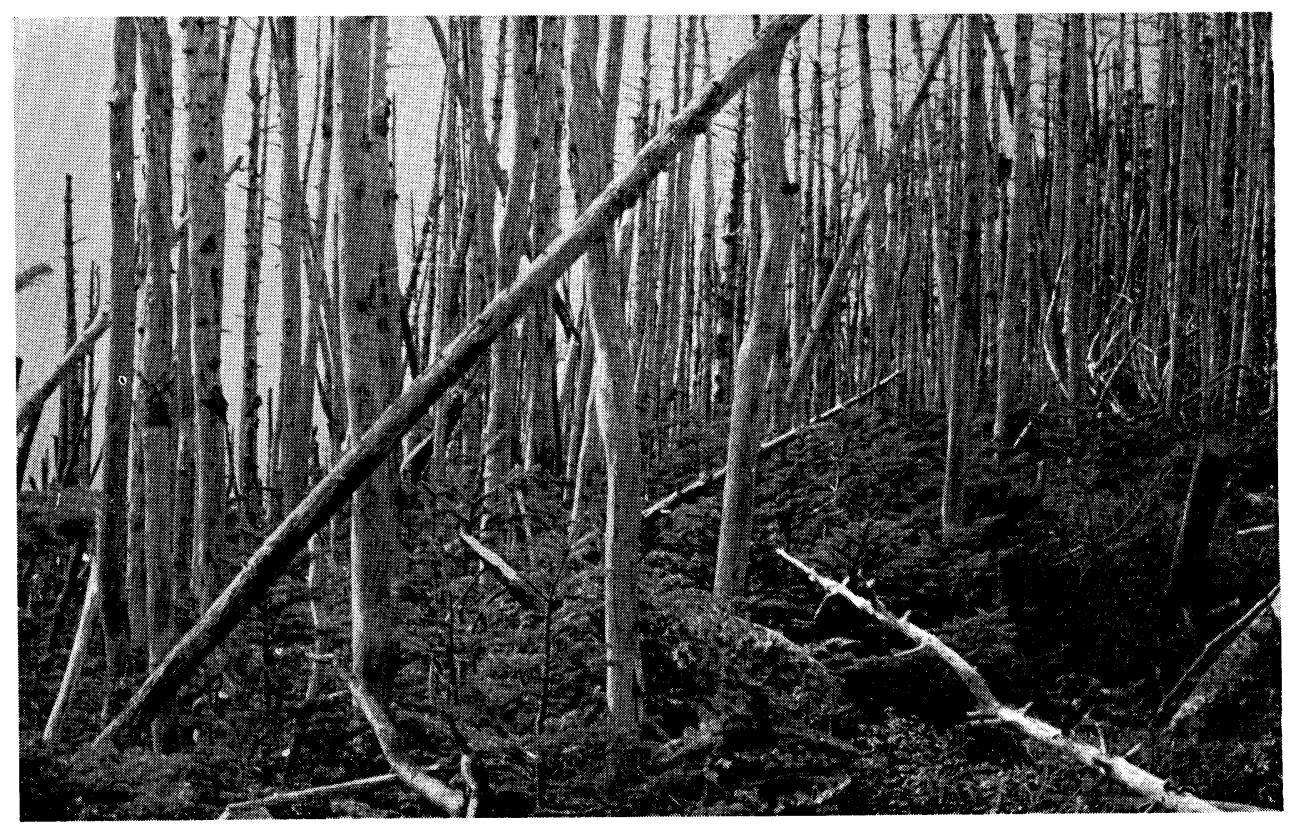

Photo 3. "Dead trees strips" IV with thick vegetation of Abies Veitchii and $A$. Mariesii.

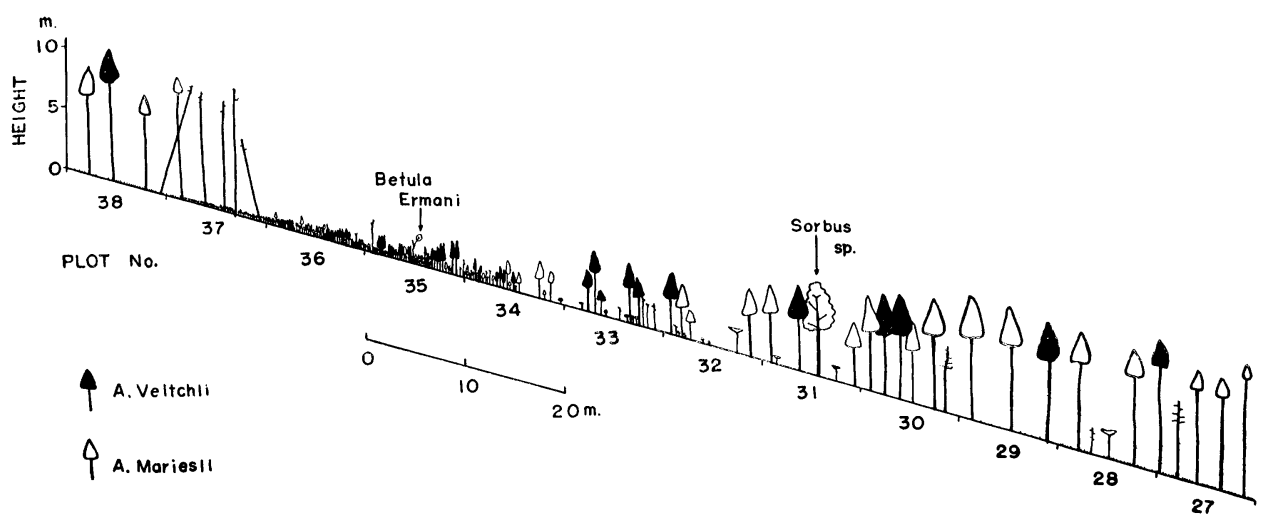

Fig. 2. Profile chart of Forest Unit IV on Transect I (West). 
Table 1. Temperature and precipitation in the range of Mt. Shimagare. The temperatures at $2250 \mathrm{~m}$., and $2395 \mathrm{~m}$. are extrapolated from the data at Kitayama and Kirigamine.

\begin{tabular}{l|c|c|c|c|c|c}
\hline & \multicolumn{2}{|c|}{ Kitayama } & \multicolumn{2}{c|}{ Kirigamine } & \multicolumn{2}{c}{ Shimagare } \\
\hline $\begin{array}{l}\text { Alti- } \\
\text { tude }\end{array}$ & \multicolumn{2}{|c|}{$985 \mathrm{~m}}$. & \multicolumn{2}{c|}{$1925 \mathrm{~m}}$. & $2250 \mathrm{~m}$. & $2395 \mathrm{~m}$. \\
\hline & $\begin{array}{c}\text { mean air } \\
\text { tempd } \\
(1916 \sim 40)\end{array}$ & $\begin{array}{c}\text { precipita- } \\
\text { tion } \\
(1897 \sim 1944)\end{array}$ & $\begin{array}{c}\text { mean air } \\
\text { temp. } \\
(1944 \sim 46)\end{array}$ & $\begin{array}{c}\text { precipita- } \\
\text { tion } \\
(1944 \sim 46)\end{array}$ & \multicolumn{2}{|c}{$\begin{array}{c}\text { mean air } \\
\text { temperature } \\
\text { (calculated) }\end{array}$} \\
\hline Jan. & $-3.2^{\circ}$ & $41 \mathrm{~mm}$. & $-10.5^{\circ}$ & $23 \mathrm{~mm}$. & $-13.0^{\circ}$ & $-14.2^{\circ}$ \\
Feb. & -2.7 & 57 & -10.7 & $59 *$ & -13.5 & -14.7 \\
March & 1.2 & 73 & -6.3 & 89 & -8.9 & -10.1 \\
April & 8.0 & 104 & 0.9 & 130 & -1.6 & -2.7 \\
May & 12.7 & 103 & 5.8 & 136 & 3.9 & 2.4 \\
June & 17.0 & 172 & 11.3 & 194 & 9.3 & 8.4 \\
July & 21.1 & 178 & 14.4 & 240 & 12.1 & 11.1 \\
Aug. & 20.6 & 117 & 15.7 & 167 & 14.0 & 13.3 \\
Sep. & 17.8 & 119 & 11.6 & 176 & 9.5 & 8.5 \\
Oct. & 11.4 & 120 & 6.3 & 283 & 4.5 & 3.8 \\
Nov. & 5.9 & 69 & 0.5 & 88 & -1.4 & -2.2 \\
Dec. & 0.2 & 46 & -8.6 & 99 & -11.6 & -13.0 \\
\hline Annual & $9.2^{\circ}$ & $1295 \mathrm{~mm}$. & 2.5 & $1683 \mathrm{~mm}$. & $0.2^{\circ}$ & $-0.8^{\circ}$ \\
\hline
\end{tabular}

*Mean precipitation in $1945 \sim 47$; abnormally high precipitation of $579 \mathrm{~mm}$. was recorded in 1944.

a slight deformation of tree crowns, and high humidity can be expected for the sake of thick fog which usually envelops the mountain.

The soil of the forest permits only shallow root development of the trees in a thin layer of brown loam of $30-40 \mathrm{~cm}$., which is covered with mosses, debris of needles and humus. Under this loamy layer there exists a layer of large gravel up to 60$80 \mathrm{~cm}$. depth on unweathered andesite rocks. Any speciality of substratum was not recognized at the dead trees strips (cf. also Yoshida and Yamanouchi 1955).

\section{Structure of the forests and the dead trees strips}

As mentioned above, the Abies forest on the southwestern slope of Mt. Shimagare can be separated into several forest units which are imbricating with each other. A forest unit consists of young tree growth in the upper part, of mature trees in the middle, and of overmatured ones in the lower part, ending in a dead trees strip. About six dead trees strips (Fig. 1), of which width is ca. $10 \mathrm{~m}$., and length $300-800 \mathrm{~m}$., are running on the slope along contour lines, almost in parallel with each other at intervals of about $100 \mathrm{~m}$. The lowest dead trees strip (VI) situates at the $2250 \mathrm{~m}$. above the sea, and a part of the highest strip (I) reaches the mountain top of $2395 \mathrm{~m}$. and these areas fall in the natural distribution range of these Abies, as Imanishi2) reported that the distribution range of $A$. Veitchii in the northern 
Japanese Alps is $1636-2337 \mathrm{~m}$. and that of A. Mariesii $1965-2550 \mathrm{~m}$. The mixing proportion of $A$. Mariesii increases gradually towards the mountain top, at the cost of decreasing of the number of $A$. Veitchii.

In order to study the structure of the forest unit more precisely, two transects of about $250 \mathrm{~m}$. long were laid down along the southwest slope, with an interval of $30 \mathrm{~m}$., across the middle of the dead trees strips III, IV and Va. Quadrats of $1 \mathrm{~m} . \times$ $1 \mathrm{~m}$. were employed at the younger tree stands because of dense and fairly homo-

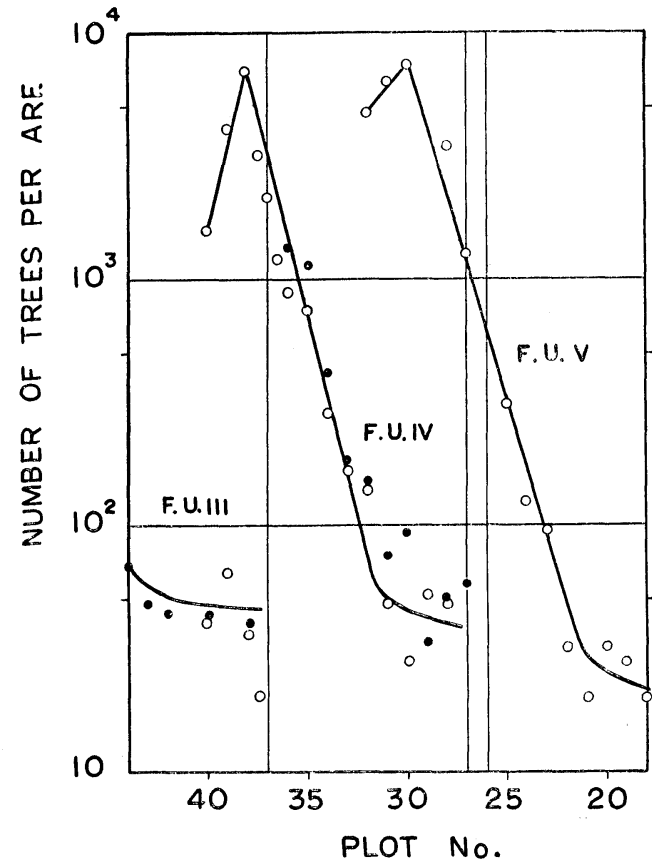

Fig. 3. Change of tree densities against descending the slope. Open circles show the data from Transect II and filled ones those from Transect 1. Vertical lines correspond to the location of "dead trees strips" III and IV. genous growth, but in the older tree stands, branch transects of $5 \mathrm{~m} . \times 100 \mathrm{rn}$. perpendicular to the main transects or parallel to contour lines were adopted to get average values from the forest stands where the mature and overmature trees of larger size distribute rather heterogenously. The followings were measured in this investigation: density of yearlings and trees, height of plants, diameter breast high (over $3 \mathrm{~cm}$.) or basal diameter (on the tree smaller than $3 \mathrm{~cm}$. d. b. h.), diameter of crown, etc. Some standard trees also were selected from each plot for stem analysis, etc. (Tab. 3). The profile chart of the vegetation on Transect I (West) in Forest Unit III-IV is illustrated in Fig. 2, and the main results of Transect II (East) are summarized in Table 1.

Remarkable changes along with descending the slope in a forest unit are the increase of age and height. and the decrease of number of trees. At the dead trees strips there occurs the regeneration of young thick growth of Abies Veitchii and A. Mariesii. This young mixed growth continues beyond the dead trees strip upwards to the seedlings under the canopy of the upper forest unit, as the germination of Abies trees and the establishment of the seedlings are going under the matured Abies trees at the in-between of the dead trees strip and another upper one. Downwards out of the forest canopy, the trees increase their heights and ages but decrease their density, forming a new lower forest canopy with mature and overmature trees. Then comes another or lower dead trees strip. The number of young growth increased in the seedling and very young tree stage with increase of plant age or downwards on the slope (see Fig. 3 and Tab. 2). After reaching the highest density at somewhat high above the upper dead 
Table 2. Change of the densities of Abies Veitchii and A. Mariesii on Transect II (East) acrossing the middle of Forest Units III, IV and Va. The "suppressed" trees have their crowns clearly under those of "canopy trees," but they are distinguished from young growth in their morphology as well as in supposed age. The mark * shows the position of the "dead trees strip".

\begin{tabular}{|c|c|c|c|c|c|c|c|c|}
\hline \multirow{3}{*}{$\begin{array}{l}\text { Forest } \\
\text { Unit }\end{array}$} & \multicolumn{2}{|c|}{ Situation } & \multicolumn{6}{|c|}{ No. of trees per are } \\
\hline & \multirow{2}{*}{$\mathrm{m}$. } & \multirow{2}{*}{$\begin{array}{l}\text { Plot } \\
\text { No. }\end{array}$} & \multicolumn{3}{|c|}{ Canopy tree } & \multirow{2}{*}{$\begin{array}{l}\text { Young } \\
\text { growth }\end{array}$} & \multirow{2}{*}{$\begin{array}{c}\text { Sup- } \\
\text { pressed }\end{array}$} & \multirow{2}{*}{$\begin{array}{c}\text { Dead } \\
\text { trunk } \\
\text { standing }\end{array}$} \\
\hline & & & A. Veitchii & A. Mariesii & Total & & & \\
\hline \multirow{6}{*}{ III } & $0 \sim 5$ & 40 & 28 & 12 & 40 & 1534 & - & 44 \\
\hline & $10 \sim 15$ & 39 & 32 & 32 & 64 & 4030 & 4 & 12 \\
\hline & $20 \sim 25$ & \multirow{2}{*}{38} & 20 & 16 & 36 & 6866 & 24 & 24 \\
\hline & $25 \sim 30$ & & 8 & 12 & 20 & 3200 & 60 & 8 \\
\hline & $30 \sim 35$ & 37 & 1750 & 400 & 2150 & 一 & 一 & 200 \\
\hline & $35 \sim 40$ & & 850 & 350 & 1200 & - & - & 1500 \\
\hline \multirow{11}{*}{ IV } & $40 \sim 50$ & 36 & 383 & 508 & 891 & 一 & - & 358 \\
\hline & $50 \sim 60$ & 35 & 600 & 167 & 767 & 一 & 83 & 350 \\
\hline & $60 \sim 70$ & 34 & 125 & 163 & 288 & 一 & 25 & 250 \\
\hline & $70 \sim 80$ & 33 & 80 & 88 & 168 & 600 & 12 & 68 \\
\hline & $80 \sim 90$ & 32 & 68 & 72 & 140 & 4767 & 16 & 44 \\
\hline & $90 \sim 100$ & 31 & 28 & 20 & 48 & 6367 & 20 & 36 \\
\hline & $100 \sim 110$ & 30 & 12 & 16 & 28 & 7475 & 12 & 12 \\
\hline & $110 \sim 120$ & 29 & 16 & 36 & 52 & - & - & 52 \\
\hline & $120 \sim 130$ & 28 & 20 & 28 & 48 & 3460 & 8 & 36 \\
\hline & $130 \sim 140$ & 27 & 500 & 780 & 1280 & - & - & 180 \\
\hline & $140 \sim 150$ & 26 & 575 & 450 & 1025 & 一 & 一 & 112 \\
\hline \multirow{10}{*}{ V } & $150 \sim 160$ & 25 & 175 & 137 & 312 & - & 112 & 200 \\
\hline & $160 \sim 170$ & 24 & 50 & 75 & 125 & - & 12 & 150 \\
\hline & $170 \sim 180$ & 23 & 48 & 48 & 96 & - & 20 & 64 \\
\hline & $180 \sim 190$ & 22 & 8 & 24 & 32 & - & 16 & 28 \\
\hline & $190 \sim 200$ & 21 & 8 & 12 & 20 & - & - & 12 \\
\hline & $200 \sim 210$ & 20 & 16 & 16 & 32 & 一 & - & 28 \\
\hline & $210 \sim 220$ & 19 & 12 & 16 & 28 & 2600 & - & 20 \\
\hline & $220 \sim 230$ & 18 & 4 & 16 & 20 & 4890 & - & 6 \\
\hline & $230 \sim 240$ & 17 & - & 2 & 2 & 1647 & - & 24 \\
\hline & $240 \sim 250$ & 16 & - & - & - & 950 & - & 26 \\
\hline
\end{tabular}

trees strip, the growing trees diminished in their number rapidly towards the lower dead trees strip with a constant decreasing rate, except for in a stable state of overmature stands.

Change in age, tree diameter and height in the forest unit IV with the descending the slope will be seen in Table 3. The mean height of young trees just in the dead trees strip III was $1 \mathrm{~m}$. or less, and the mature tree at 60-70 m. downwards from the strip III, reached a maximum height of $10.3 \mathrm{~m}$. After Yoshida and Yamanouchi,12) 
Table 3. Age, diameter breast high, and height of standard trees in Forest Unit IV. Plot Nos, correspond to those in Table 2.

\begin{tabular}{c|c|c|c|c|c|c}
\hline & \multicolumn{3}{|c|}{ Abies Veitchii } & \multicolumn{3}{c}{ Abies Mariesii } \\
\hline Plot No. & Age & $\begin{array}{c}\text { D. B. H. } \\
\text { (cm.) }\end{array}$ & $\begin{array}{c}\text { Height } \\
\text { (m.) }\end{array}$ & Age & $\begin{array}{c}\text { D. B. H. } \\
\text { (cm.) }\end{array}$ & $\begin{array}{c}\text { Height } \\
\text { (m.) }\end{array}$ \\
\hline 36 & 17 & - & 0.96 & 18 & - & 1.05 \\
35 & 30 & 2.6 & 2.27 & 29 & 2.2 & 2.05 \\
$34 \sim 33$ & 41 & 4.8 & 3.76 & 41 & 4.4 & 3.70 \\
32 & 61 & 7.4 & 6.40 & 64 & 7.6 & 6.00 \\
30 & 73 & 10.4 & 7.62 & 78 & 9.2 & 7.55 \\
28 & 86 & 14.0 & 9.60 & 70 & 14.0 & 10.10 \\
27 & 83 & 14.1 & 10.33 & 97 & 14.6 & 10.25 \\
\hline
\end{tabular}

the maximum heights of trees are different with altitude of the slope where the trees are standing, e. g. at the forest unit II $(2380 \mathrm{~m}$.) it was $7.6 \mathrm{~m}$ and at the forest unit VI $(2250 \mathrm{~m}$.) $13.4 \mathrm{~m}$. However, comparing to the normal growth of Abies of 20$25 \mathrm{~m}$. high on better sites, the growth of the trees on the southwest slope of Mt. Shimagare seems to be generally worse. The maximum diameter breast high of 14 $\mathrm{cm}$. also seems to be obviously too small in comparison with that the mature trees have sometimes trunks of over $60 \mathrm{~cm}$. d. b. h. in better sites. Mean maximal crown diameter of $5.5 \mathrm{~m}$. was observed on the trees just matured standing in the plots at $30-40 \mathrm{~m}$. above the dead trees strip (see Fig. 1). The overmatured trees above $10 \mathrm{~m}$. upwards of the dead trees strip have rather smaller crown diameter of 2.5-3.0 m.

In general, the vigorous regeneration of the overpopulated young trees of both the Abies species ${ }^{12)}$, and the undersized mature and overmature trees are the characteristics in the forests on the southwest slope of Mt. Shimagare.

\section{Weight of leaves, branches and trunk}

On the several standard trees selected in various growing stages, the dry weight of each organs, such as leaves, branches and trunk, except for root system, were measured respectively, because the leaf amount determines the light condition on the forest floor which plays important role in the direction of plant succession, and the ratio between leaves (=photosynthetic system), and branch, trunk (and root) (=nonphotosyntheic system) is an important measure for the carbohydrate economy in plants or consequently for growth of trees.4),5)

Descending the slope or with increase of tree age, the dry weight of leaves on a standard tree increased, and it reached its maximum of mature tree with gradual decrease of increment rates (Fig. 4). About $2.8 \mathrm{~kg}$. per plant was obtained as a maximum in A. Mariesii, and $1.8 \mathrm{~kg}$. in A. Veitchii. The overmatured tree just above the dead trees strip bore a very small deteriorated crown on its top, and its leaf weight was nearly half of the maximum in the just matured tree. On the contrary the total weight of bole and branches increased steadily with age of tree (or downwards on the slope). Therefore, the ratio of non-photosynthetic system increases with age 
of tree, e. g. in younger trees the ratio is only 3 (Mariesii) - 5 (Veitchii), in mature ones about 5 (Mariesii)-10 (Veitchii), but in overmatured ones 19 (Mariesii)-24 (Veitchii). This suggests that the balance between photosynthesis and respiration becomes worse with overmaturing up to the death of trees.

Also it should be mentioned here that the weight of leaves in A. Mariesii always exceeded that of A. Veitchii in the same age or in the same plot number, in spite of that no difference was recognized in the weight of aerial part between two Abies species. Therefore, the ratio of non-photoynthetic system to photosynthetic one is larger in $A$. Veitchii than another Abies throughout the whole ages.

\section{Light intensity in the forest}

Light usually influences upon

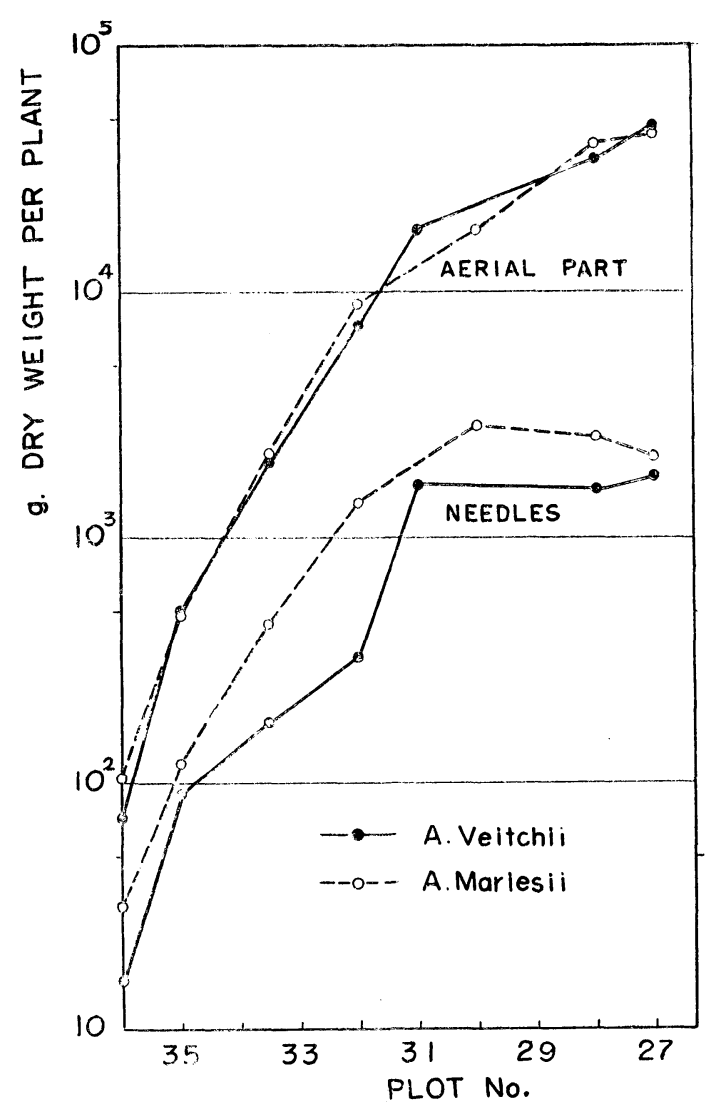

Fig. 4. Change of dry weight of needles and of total aerial part of the standard Abies trees in Forest Unit IV. the natural regeneration of forest, as one of the most essential factors. Therefore, relative light intensity was determined with two photometers (Toshiba No. 5), a photocell of which was fixed at a considerable height over the young canopy at an opening in the dead trees strip to get the full light intensity, another was moved along the main transect I under the canopy of the forest unit IV. Those measurements were done under cloudy skies to get the values which respond to the structure of the forest canopy6). Average value of ten observations is shown in Fig. 5.

Under the young growth at the dead trees strip III the relative light intensity was 7-25\%, but only at $10 \mathrm{~m}$. downwards there came a minimal intensity of only $1-6 \%$, in average $4 \%$, under the thick vigorous growth of over populated young Abies trees. Hereafter the light intensity under forest canopy increased quite slowly as far as $30 \mathrm{~m}$. upwards from the dead tree strip IV. The average light intensities under such a mature tree canopy were $7-11 \%$. In the overmatured tree zone abrupt increase of light intensity came with the deterioration of the tree crowns. At the dead trees strip IV, the value observed just upon the canopy of young growth of the 


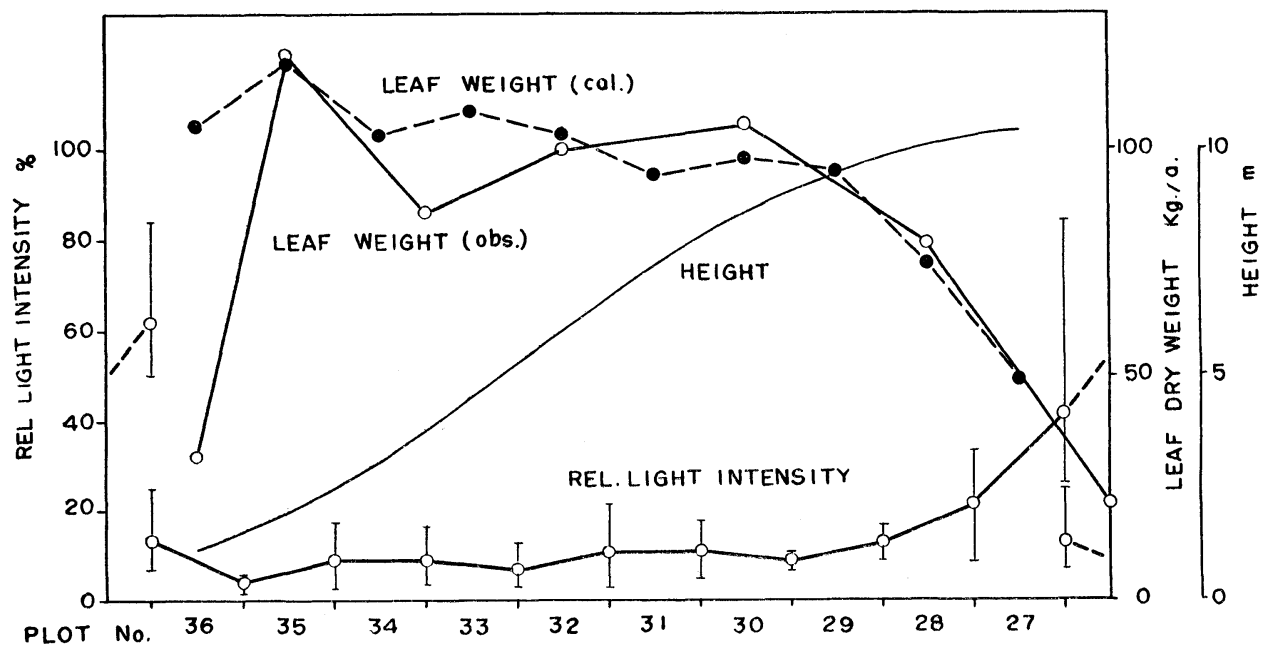

Fig. 5. Relative light intensity, height of trees and total leaf per ground area in Forest Unit IV.

forest unit $\mathrm{V}$ was $25-85 \%$, in average ca. $42 \%$, but under the canopy low illumination of $13 \%$ was obtained. Young succeeding growth, or establishment of seedlings started with low density under the somewhat immature tree stands of Abies (Plot No. 33), in the illumination of about $10 \%$. The density of the tree offspring increased rapidly with the growth of the plants or spatially in a short distance downward of the slope. The highest density came under the forest stand just overmaturing. As to the tolerance of young growth, particulary as to difference between that of A. Mariesii and A. Veitchii, further investigations will be expected.

The light intensity in the plant community is mainly decided by the amount of leaves per unit ground area ${ }^{5)}$. The amount (dry weight) of leaves per are was, though very roughly, estimated from the data of leaf amount of each standard tree and the tree number per are (see Fig. 5). The value in the young growth at the dead trees strip III was $32 \mathrm{~kg}$./a., but the value increased rapidly up to the maximum of $121 \mathrm{~kg} . / \mathrm{a}$. at $10 \mathrm{~m}$. downward from that strip. Downwards of this area somewhat constant leaf amount of $86-105 \mathrm{~kg}$./a., was prevailing. From $20 \mathrm{~m}$. upward from the strip IV the leaf amount decreased strikingly, and the value of overmatured stand just upward of the dead trees strip IV was only about $21 \mathrm{~kg}$. $/$ a. It may be recognizable that the light intensity under canopy and the leaf amount in the canopy have just opposing trends in the variations. This will be proved more clearly by the coincidence of the leaf amount calculated from the light intensities4),5) with the observed values mentioned above. The discrepancy between the two values at the youngest stage seems to be caused by interception of the vigorous growth of other herbs and shrubs in the herb stratum. 


\section{Undergrowth}

Frequency and dominancy of the undergrowth were investigated at 51 quadrats of $1 \mathrm{~m} . \times 1 \mathrm{~m}$. along the transects, according to Braun-Blanquet's general estimation method. Some results are briefly summarized in Tab. 4. Almost all of the 22 species obtained in the undergrowth of this forest were the common shade plants in the subalpine coniferous forest in central Japan. The highest dominancy and frequency were observed, excepting mosses, in Pteridophyllum racemosum which is one of the character species in Abietum, and Nakanos),9) denominated such a sociation as Pteridophyllosum. However, the undergrowth species maintained in general rather poor dominancy because of low illumination under the canopy of the Abies trees and vigorous regeneration of young growth of the dominant trees. Total standing crop of undergrowth is, generally speaking, decided by the illumination prevailing over the undergrowth $\left.{ }^{2)}, 6\right)$. Therefore, there was almost no growth in the shade of 3-4\% light intensity under the thick young growth of tree species at $10 \mathrm{~m}$. downward from the dead trees strip III. With development of the forest, the obligate shade plants such as $P$. racemosum and Oxalis japonica arose but with low dominance. Only in

Table 4. Frequency and dominancy of main species of undergrowth which included 22 species. The values were calculated from the data of 51 quadrats of $1 \mathrm{~m} . \times 1 \mathrm{~m}$.

\begin{tabular}{l|c|c}
\hline \multicolumn{1}{c|}{ Species } & $\begin{array}{c}\text { Frequency } \\
(\%)\end{array}$ & Dominancy \\
\hline Pteridophyllum racemosum & 98 & $2 \sim 4$ \\
Oxalis japonica & 88 & $1 \sim 3$ \\
Carex lanceolata & 84 & $1 \sim 3$ \\
Cornus canadenisis & 73 & $1 \sim 2$ \\
Cacalia adenostyloides & 63 & $1 \sim 2$ \\
Rubus japonicus & 61 & $1 \sim 2$ \\
Majanthemum bifolium & 59 & 1 \\
Pirola alpina & 43 & + \\
Dryopteris sp. & 75 & $1 \sim 3$ \\
Mosses & 96 & $3 \sim 5$ \\
\hline
\end{tabular}

the place where the trees matured or overmatured and their crowns were somewhat or badly deteriorated, the vigorous growth of herbaceous or shrubby undergrowth, such as Cacalia adenostyloides, Carex lanceolata, Cornus canadensis was expected, accompanied by rapid development of young Abies trees. As to the species number in each quadrat, however, any direct relationship to the light intensities could not be recog nized 3 .

\section{Summary}

1. The subalpine coniferous forest on the southwestern slope of Mt. Shimagare in Nagano Pref., central Japan, is characterized with about six transverse " dead trees 
strips" (width $=10 \mathrm{~m}$., length $=300-800 \mathrm{~m}$., interval $=100 \mathrm{~m}$.) where a large number of dead tree trunks of the dominant trees, Abies Veitchii and A. Mariesii, stand or fall so densely that the strips are seen as whitish stripes in a distant view.

2. The natural regeneration of dominant trees emerges under the canopy of mature trees in in-between of two dead trees strips. Vigorous young mixed growth of Abies species continues downwards beyond a dead trees strip of the covering canopy. Out of the canopy, the trees become larger and older, and they form a new canopy which consists of serially growing crowns, up to the overmatured and just dying trees of another dead trees strip at lower altitude.

3. Plant density, ages, heights, diameters breast high, top weights, leaf weights, undergrowth, etc., were investigated with quadrat method and in the standard trees. The density of overpopulated young trees decreased with maturing of trees by a constant rate. Vigorous regeneration of the two Abies species, and poor mature and overmature stands of small sized trees make the characteristics of the forest.

4. The leaf weight increased from a young tree to mature one, but in overmature tree it slightly decreased, accompanying the high increase of relative weight of nonphotosynthetic system. The leaf amount in unit ground area, however, was highest at somewhat younger tree stands because of high density of young growth, and it abruptly decreased in the overmature stands.

5. The dominancy of undergrowth was markedly influenced by light intensity of the forest floor, for which the leaf weight of the dominant trees was highly responsible.

The authors wish to express their thanks to Prof. K. Hogetsu and Prof. M. Monsi for helpful suggestions and valuable advice. Their deep gratitude is also due to Mr. K. Yoshida and Mr. Y. Okanishi for kind help during the investigation. A part of the expenses of this study was defrayed with a grant-in-aid from the Research Fund of the Ministry of Education.

\section{References}

1) Boysen-Jensen, P., Die Stoff produktion der Pflanzen, Jena (1932). 2) Daxer, H., Jahrb.f. wiss. Bot. 80: 363 (1934). 3) Imanishi, K., Bull. Biogeog. Soc. Jap., 9: 133 (1993) 4) Iwaki, H., Jap. Journ. Bot. 16:210 (1958). 5) -_ dissertation (1958). 6) Monsi, M. and Saeki, T., Jap. Journ. Bot. 14:22 (1953). 7) —— and Oshima, Y., ibid. 15:60 (1955). 8) Nakano, H., Ann. of Phytoecol. Japan, 2: 1 (1942). 9)—, Bot. Mag. Tokyo, 56: 186 (1942). 10) Okubo, K., Jap. Forest Soc. 15:652 (1938). 11). Wagner, C., Der Blendersaumschlag und sein System, Tübingen (1915). 12) Yoshida, K. and Yamanouchi, S., Rep. Silv. Tech. (Zorin Gijutsu Kenkyu) 5: 53 (1955). 


\section{摘 要}

縞枯山は長野県北八ケ岳にある標高 2395 メートルの山で, その南西斜面には約 6 条の白い縞（幅： 10 メートル，長さ：300-800 メートル，間隔：100 メートル）が, 主としてシラビソ, オオシラビソからなる 亜高山带針葉樹林の浱緑色の中を水平に走っている。この白い横縞はこれら針葉樹の立枯れの幹が带状に 密集してできたものである。優占樹木の武生えは二つの縞の中間にある成木の樹冠下に発生し，その下方の 縞を通りぬけ，斜面を下るにしたがって樹令や大きさを増し，稚樹，成木，過熟木の段階を経て，ついには 枯死木となり，一段下の縞枯部を形成している。

調查の第一歩として, 斜面の中ほどの一連の生育相について, ワク法, あるいは標準木法を用い, 立木密 度, 樹令, 樹高, 胸高直径, 地上部重, 葉重, 下草などを調べた。立水密度は過密な稚樹相から成木相に 向かって一定の割合で減少し，成木から過熟木まではあまり減少しない。1 本あたりの葉量は稚樹から成木 までは増加寸るが, 成木から過熟木に向かっては減少し, それに伴って光合成器官 (葉)の非光合成器官 (幹 十枝)に対寸る重量此も急激に減少寸る。林分の単位面積あたりの葉量の最大は, 縞枯部のやや下方の密生 した稚樹のとてろにあり，それから成木のとてろまではあまり減少しないが，縞枯部近くで急减する。“林 内相対照度はこのような葉量の変化に対応した変化を示し, 下草の優占度はこの林内照度によって影響され ていることが明らかにされた。 